\title{
Congenital short bowel syndrome: A case report and review of the literature
}

\author{
Mohammed Hasosah MD ${ }^{1}$, Daniel A Lemberg MBBS FRACP ${ }^{1}$, \\ Eric Skarsgard MD FRCSC ${ }^{2}$, Richard Schreiber MD FRCP ${ }^{1}$
}

M Hasosah, DA Lemberg, E Skarsgard, R Schreiber. Congenital short bowel syndrome: A case report and review of the literature. Can J Gastroenterol 2008;22(1):71-74.

Congenital short bowel syndrome (SBS) is a rare condition of the newborn, with several reports demonstrating high mortality. A sixweek-old boy presented with chronic diarrhea and failure to thrive. An upper gastrointestinal endoscopy showed a straight duodenum, and multiple small bowel biopsies were histologically normal. An upper gastrointestinal series showed malrotation. At laparotomy, the small bowel was $50 \mathrm{~cm}$ in length, confirming the diagnosis of congenital SBS. Parenteral nutrition was initiated and enteral feeding with an amino acid-based formula containing long-chain fatty acids was introduced early and gradually advanced. At the last follow-up examination at 24 months, he was thriving on a regular diet, with normal growth and development. Long-term survival of children with congenital SBS is now possible if enteral feeds are introduced early to promote intestinal adaptation, with subsequent weaning off parenteral nutrition.

Key Words: Gastrointestinal; GI; Parenteral nutrition; PN; SBS; Short bowel syndrome

Chort bowel syndrome (SBS) is a clinical disorder that is $\checkmark$ characterized by diarrhea and malabsorption following the functional or anatomical loss of enough small bowel length to markedly compromise intestinal absorptive capacity (1). In neonates, SBS is most often recognized as an acquired disorder following surgical bowel resection for conditions such as necrotizing enterocolitis or intestinal atresia. However, in rare instances, the SBS may be congenital in origin, with the neonatal bowel being short in length at birth. The etiopathogenesis of congenital SBS is unknown and several reports have noted high mortality for these cases $(2,3)$. The present paper describes a term infant with congenital SBS who presented with chronic diarrhea and failure to thrive and survived into infancy after having successfully weaned from parenteral to full enteral nutrition. A review of the literature on congenital SBS is also provided.

\section{CASE PRESENTATION}

A six-week-old Caucasian boy presented with chronic watery diarrhea and failure to thrive. He was the product of a term pregnancy from nonconsanguineous parents and his delivery was normal. His birth weight was $3.24 \mathrm{~kg}$. He was discharged at two days of age and was strictly breastfed. Three days later, watery, explosive nonbloody diarrhea developed, without

\section{Syndrome congénital de l'intestin court : Rapport de cas et revue de la littérature}

\begin{abstract}
Le syndrome congénital de l'intestin court (SIC) est une maladie rare du nouveau-né associée à plusieurs rapports de mortalité élevée. Un garçonnet de six semaines a été amené pour diarrhée chronique et retard de croissance. Une endoscopie des voies digestives hautes a révélé un duodénum droit et plusieurs biopsies du grêle se sont révélées normales sur le plan histologique. Un transit des voies digestives hautes a montré une rotation anormale. À la laparotomie, le grêle mesurait $50 \mathrm{~cm}$, confirmant le diagnostic de SIC congénital. La nutrition parentérale a été instaurée et une alimentation entérale avec préparation à base d'acides aminés renfermant des acides gras à chaîne longue a été débutée tôt et a graduellement progressé. Au moment du dernier examen de suivi, à 24 mois, l'enfant connaissait une croissance et un développement normaux avec une diète régulière. Il est désormais possible d'obtenir une survie à long terme chez les enfants atteints de SIC congénital si l'alimentation entérale est débutée tôt afin de favoriser l'adaptation intestinale , suivie d'un sevrage de la nutrition parentérale.
\end{abstract}

vomiting, and continued despite elimination of dairy products from the maternal diet. With no improvement by two weeks of age, breastfeeding was discontinued and multiple formulas were tried, including lactose-free and protein hydrolysate feeds, over the ensuing four weeks. At referral, the child weighed $3.35 \mathrm{~kg}$ (smaller than the third percentile) and his length was $65 \mathrm{~cm}$ (within the 25th percentile). He appeared clinically well, with no dysmorphic features, jaundice, ascites, edema, rash or mouth lesions. His abdomen was soft, with only mild distension. There was no organomegaly. Laboratory studies demonstrated hemogobin levels at $112 \mathrm{~g} / \mathrm{L}$, white blood cell count at $10.0 \times 10^{9} / \mathrm{L}$, with a normal differential count (no eosinophilia) and a platelet count of 544,000. Serum electrolytes, bicarbonate, glucose, albumin, total protein, transaminases and immunoglobulins were normal. A sweat chloride test was negative. Stool samples were negative for leukocytes, occult blood, culture, ova and parasites. Urine cultures were negative. A plain film of the abdomen was unremarkable. An upper gastrointestinal (GI) endoscopy revealed a straight duodenum through to the third stage. Multiple small bowel biopsies exhibited normal villous architecture without an inflammatory infiltrate or features for lymphatic dilation. An upper GI series showed malrotation with the duodenojejunal flexure positioned in the right midabdomen

\footnotetext{
${ }^{1}$ Department of Gastroenterology; ${ }^{2}$ Department of Surgery, British Columbia Children's Hospital, University of British Columbia, Vancouver, British Columbia

Correspondence: Dr Mohammed Hasosah, Department of Pediatric Gastroenterology, British Columbia Children's Hospital, 4480 Oak Street,

Vancouver, British Columbia V6H 3V4. Telephone 604-875-5363, fax 604-875-3244, e-mail myhasasah@yahoo.com

Received for publication October 6, 2006. Accepted February 22, 2007
} 
TABLE 1

Reported cases of congenital short bowel syndrome

\begin{tabular}{|c|c|c|c|c|c|}
\hline Reference & Year & $\begin{array}{c}\text { Cases, } \\
n\end{array}$ & $\begin{array}{c}\text { Bowel } \\
\text { length, } \\
\text { cm }\end{array}$ & Malrotation & Outcome* \\
\hline \multirow[t]{2}{*}{ Hamilton et al (4) } & 1969 & 2 & 40 & Yes & $\mathrm{S}>6$ years \\
\hline & & & 30 & Yes & D 1 month \\
\hline Konvolinka (22) & 1970 & 1 & 30 & Yes & D 5 months \\
\hline Kern et al (23) & 1973 & 1 & 70 & Yes & D 5 months \\
\hline Yutani et al (24) & 1973 & 1 & 42 & Yes & D 1 month \\
\hline $\begin{array}{l}\text { Dumke and } \\
\text { Schnoy (25) }\end{array}$ & 1974 & 1 & 106 & Yes & D 1 month \\
\hline \multirow[t]{4}{*}{ Royer et al (26) } & 1974 & 4 & 40 & Yes & D 1 month \\
\hline & & & 45 & Yes & D 7 months \\
\hline & & & 70 & Yes & D 2 months \\
\hline & & & 25 & Yes & D 3 weeks \\
\hline \multirow[t]{2}{*}{ Tanner et al (12) } & 1976 & 2 & 40 & Yes & D 5 months \\
\hline & & & 75 & Yes & D 1 day \\
\hline Schnoy et al (27) & 1978 & 1 & 65 & Yes & D 3 months \\
\hline \multirow[t]{2}{*}{ Sansaricq et al (11) } & 1984 & 2 & 65 & Yes & D 2 months \\
\hline & & & 72 & Yes & $S>5$ years \\
\hline \multirow[t]{2}{*}{ Shawis et al (28) } & 1984 & 2 & 45 & Yes & D 4 months \\
\hline & & & 45 & Yes & D 1 month \\
\hline \multirow[t]{2}{*}{ Tiu et al (29) } & 1984 & 2 & 24 & Yes & D 2 months \\
\hline & & & 27 & Yes & D 5 months \\
\hline Iwai et al (30) & 1985 & 1 & 45 & Yes & D 2 months \\
\hline Dorney et al (31) & 1986 & 1 & 69 & Yes & $S>7$ years \\
\hline \multirow[t]{3}{*}{ Kern et al (3) } & 1990 & 3 & 112 & Yes & D 1 month \\
\hline & & & 55 & Yes & D 6 months \\
\hline & & & 237 & Yes & $S>18$ years \\
\hline Huysmane et al (32) & 1991 & 1 & 54 & Yes & $S>4$ years \\
\hline De Backer et al (33) & 1997 & 1 & 50 & Yes & $S>3$ years \\
\hline Sarimurat et al (13) & 1998 & 1 & 25 & No & D 6 months \\
\hline Aviram et al (10) & 1998 & 1 & 35 & Yes & D 9 weeks \\
\hline Schalamon et al (34) & 1999 & 1 & 47 & Yes & $S>1.5$ years \\
\hline \multirow[t]{4}{*}{ Erez et al (2) } & 2001 & 4 & 42 & Yes & D 5 months \\
\hline & & & 51 & Yes & D 1 month \\
\hline & & & 95 & Yes & $S>15$ years \\
\hline & & & 35 & Yes & D 9 weeks \\
\hline Chu et al (20) & 2004 & 1 & 20 & Yes & $S>15$ months \\
\hline Sabharwal et al (21) & 2004 & 1 & 56 & Yes & $S>12$ months \\
\hline Ordonez et al (35) & 2006 & 1 & 30 & Yes & $S>7$ years \\
\hline Hasosah et al & 2008 & 1 & 50 & Yes & $S>2$ years \\
\hline
\end{tabular}

${ }^{*}$ Times relative to outcomes are presented as weeks, months or years of age. $S$ Survived; D Died

and, as a result, he underwent a Ladd operation. At laparotomy, the small bowel length was measured to be $50 \mathrm{~cm}$ from the duodenum to the ileocecal valve. Postoperatively, he received central parenteral nutrition (PN). Oral feeding with a glucose polymer, amino acid-based formula with $95 \%$ long-chain fatty acids (Neocate, Nutricia North America) was introduced early and gradually increased as the PN diminished. His course was complicated by several episodes of sepsis, with Klebsiella species and Staphylococcus species, which were treated in a standard manner with intravenous antibiotics. By eight months of age, he was receiving $70 \%$ of his total caloric requirements through enteral feeding, with the remaining 30\% by PN. Soon thereafter, the PN was discontinued and he remained on enteral formula feed, along with textured foods. He had no clinical or biochemical evidence of total PN cholestasis. At the final follow-up examination at 24 months, he was thriving on a regular oral diet for his age, with normal growth and development.

\section{DISCUSSION}

Congenital SBS, first described by Hamilton et al in 1969 (4), is a rare condition, with only 37 cases reported in the English literature (Table 1). According to several autopsy studies in children, the length of the small intestine, as measured from the Treitz ligament to the ileocecal valve, has been shown to correlate with crown-to-heel length. During somatic growth, as the crown-to-heel length increases from $40 \mathrm{~cm}$ to $100 \mathrm{~cm}$, the small bowel increases from $164 \pm 54 \mathrm{~cm}$ (mean $\pm \mathrm{SD}$ ) to $425 \pm 90 \mathrm{~cm}$ (5). Thus, the mean length of the small intestine in full-term newborns is approximately $240 \mathrm{~cm}$, increasing to $430 \mathrm{~cm}$ by 15 years of age (6). In adults, the average small bowel length is reported to be $600 \mathrm{~cm}$, with a range of $260 \mathrm{~cm}$ to $800 \mathrm{~cm}$ (7). In preterm infants, the expected jejunoileal length correlates with gestational age, with the bowel length expected to double from 28 to 40 weeks gestation (8). In full-term neonates, SBS may manifest when the small bowel length is less than $75 \mathrm{~cm}$ (9). Newborns with congenital SBS may have a significantly shortened small bowel, with intestinal lengths reported as short as $20 \mathrm{~cm}$. In the present review of reported congenital SBS, the mean small bowel length was $57 \mathrm{~cm}$ (range $20 \mathrm{~cm}$ to $237 \mathrm{~cm}$ ) (Table 1). In the present paper, the patient had a small bowel length of $50 \mathrm{~cm}$, measured at laparotomy.

The etiopathogenesis of congenital SBS is poorly understood. During normal embryogenesis, midgut lengthening begins in the fifth week of gestation, initially forming a loop that extends into the umbilical celom. Following a series of clockwise and counterclockwise rotations to accommodate further intestinal elongation and growth, the bowel returns from its ventral herniation to the abdominal cavity at approximately 10 weeks gestation, where the base of the mesentery is then fixed along the diagonal from the Treitz ligament to the ileocecal attachments. Because congenital SBS occurs most often in association with malrotation (Table 1), Hamilton et al (4) suggested that the normal elongation, rotation and herniation of the small intestine is interrupted or delayed because of a lack of space between the developing digestive tube and the umbilical celom. Aviram et al (10) reported sequential in utero sonographic features of an infant with congenital SBS, finding persistent midgut umbilical hernia at 11 weeks gestation, with an intact anterior abdominal wall without umbilical hernia at 13 weeks gestation. Some have postulated an ischemic injury to the developing intestine; however, the patency of the bowel lumen and the presence of an intact mesentery in these cases would argue against an in utero bowel infarction. Still others have focused on the possibility of defective neuroenteric development, especially because intestinal dysmotility is recognized as an important component of the congenital SBS (11). While Tanner et al (12) found abnormalities in the myenteric plexus in autopsy studies, others were unable to confirm those findings (11). This would suggest variation in the spectrum of dysmotility in cases of congenital SBS. In our patient, dysmotility was not a predominant feature. Several cases, including those in the original report by Hamilton et al (4) have occurred in a familial pattern without a uniform mode of inheritance (2). Cases of congenital SBS have been reported in association with other congenital anomalies 
including pyloric stenosis, appendiceal agenesis, acheiria, dextrocardia, hemivertebrae and patent ductus $(2,3,13)$. No specific gene mutations have yet been identified for congenital SBS.

Most infants with congenital SBS present with vomiting, diarrhea and failure to thrive, or signs and symptoms consistent with intestinal obstruction. While malrotation is an almost universal feature (present in 96\% of cases [Table 1]), associated volvulus with acute bowel infarction is an infrequent finding, perhaps because the short bowel length prevents significant intestinal twisting and subsequent ischemia. The typical presentation of chronic diarrhea and failure to thrive, as in our patient, is likely a direct consequence of the short bowel length, malabsorption and dysmotility that are the principle hallmarks of congenital SBS.

The cornerstone to the management of these cases is PN with early introduction and advancement of enteral feedings (1). While PN is necessary to provide adequate calories for growth, the delivery of nutrition parenterally has potential complications, with sepsis being a leading cause for morbidity and mortality. While the mechanisms for small bowel adaptations are multiple and complex, early and aggressive introduction of enteral feeding is a critical component $(1,14,15)$. In acquired SBS, Bines et al (16) reported that amino acid-based formulas may reduce the overall parenteral requirement and allow for augmentation of the enteral feeding regimen by improving diarrhea and vomiting, decreasing intestinal permeability and increasing disaccharidase levels in the intestine (16). Animal studies (1,17-19) have demonstrated that long-chain fatty acids are particularly trophic to the small bowel and may be an important nutrient for enhancing bowel adaptation. For these reasons, we chose an amino acid-based formula containing long-chain fatty acids for the initial enteral feeding. Because our patient was tolerating this formula and making progress, tests to

\section{REFERENCES}

1. Vanderhoof JA. Short bowel syndrome and intestinal adaptation. In: Walker WA, Durie PR, Hamilton JR, Walker-Smith JA, Watkins JB. Pediatric Gastrointestinal Disease: Pathophysiology, Diagnosis, Managment, 3rd edn. Hamilton: BC Decker, 2000:583-602.

2. Erez I, Reish O, Kovalivker M, Lazar L, Raz A, Katz S. Congenital short-bowel and malrotation: Clinical presentation and outcome of six affected offspring in three related families. Eur J Pediatr Surg 2001;11:331-4.

3. Kern IB, Leece A, Bohane T. Congenital short gut, malrotation, and dysmotility of the small bowel. J Pediatr Gastroenterol Nutr 1990;11:411-5.

4. Hamilton JR, Reilly BJ, Morecki R. Short small intestine associated with malrotation: A newly described congenital cause of intestinal malabsorption. Gastroenterology 1969;56:124-36.

5. Siebert JR. Small-intestine length in infants and children. Am J Dis Child 1980;134:593-5.

6. Requam CW, Allen RP, Akers DR. Normal and abnormal small bowel lengths: An analysis of 389 autopsy cases in infants and children. Am J Dis Child 1965;109:447-51.

7. Weser E. Nutritional aspects of malabsorption: Short gut adaptation. Clin Gastroenterol 1983;12:443-61.

8. Touloukian RJ, Smith GJ. Normal intestinal length in preterm infants. J Pediatr Surg 1983;18:720-3.

9. Wilmore DW. Factors correlating with a successful outcome following extensive intestinal resection in newborn infants. J Pediatr 1972;80:88-95.

10. Aviram R, Erez I, Dolfin TZ, Katz S, Beyth Y, Tepper R. Congenital short-bowel syndrome: Prenatal sonographic findings of a fatal anomaly. J Clin Ultrasound 1998;26:106-8. specifically assess fat absorption and carbohydrate tolerance were not performed.

Of the cases with congenital SBS reported in the literature, one-third of the patients have survived to a mean age of 5.8 years (range, one to 18 years). Two-thirds had died, with most of the deaths having occurred early in life, well before one year of age (mean age of death was 84 days [range, one day to seven months]). Interestingly, $50 \%$ of the cases who had died were reported before 1980; a time when expertise with newborn PN therapy and the availability of semi-elemental formulas were lacking. Since the year 2000, reports have shown significantly improved survival rates for these patients. These enhanced outcomes are likely due to improvements in the overall care and management of PN therapy as well as the development of novel infant formulas that both facilitate the early introduction of enteral feeding and promote intestinal adaptation $(11,20,21)$. Based on our case and other more recent experiences with congenital SBS, it appears that careful nutritional management affords these young infants a much more favourable outcome than what had been recognized in the past.

\section{CONCLUSIONS}

Congenital SBS is a rare condition of the newborn that presents with chronic diarrhea, failure to thrive or symptoms of small bowel obstruction in the first weeks of life. Although an upper GI small bowel follow-through can confirm the presence of malrotation and suggest short bowel length, the diagnosis of congenital SBS is typically established at surgical laparotomy. Our patient, with $50 \mathrm{~cm}$ of small bowel, was able to successfully wean off of PN within a few months. Long-term survival of children with congenital SBS is now possible if adequate calories are provided to stimulate growth, aggressive enteral feeds are introduced early and close monitoring is provided, especially guided toward infection control and the prompt management of line sepsis.

11. Sansaricq C, Chen WJ, Manka M, Davis D, Snyderman S. Familial congenital short small bowel with associated defects. A long term survival. Clin Pediatr (Phila) 1984;23:453-5.

12. Tanner MS, Smith B, Lloyd JK. Functional intestinal obstruction due to deficiency of argyrophil neurones in the myenteric plexus. Familial syndrome presenting with short small bowel, malrotation, and pyloric hypertropy. Arch Dis Child 1976;51:837-41.

13. Sarimurat N, Celayir S, Elicevik M, Dervisoglu S, Yeker D. Congenital short bowel syndrome associated with appendiceal agenesis and functional intestinal obstruction. J Pediatr Surg 1998;33:666-7.

14. Williamson RC. Intestinal adaptation (second of two parts). Mechanisms of control. N Engl J Med 1978;298:1444-50.

15. Dowling RH. Small bowel adaptation and its regulation. Scand J Gastroenterol Suppl 1982;74:53-74.

16. Bines J, Francis D, Hill D. Reducing parenteral requirement in children with short bowel syndrome: Impact of an amino acid-based complete infant formula. J Pediatr Gastroenterol Nutr 1998;26:123-8

17. Sukhotnik I, Mor-Vaknin N, Drongowski RA, Miselevich I, Coran AG, Harmon CM. Effect of dietary fat on early morphological intestinal adaptation in a rat with short bowel syndrome. Pediatr Surg Int 2004;20:419-24.

18. Park JH, Grandjean CJ, Hart MH, Baylor JM, Vanderhoof JA. Effects of dietary linoleic acid on mucosal adaptation after small bowel resection. Digestion 1989;44:57-65.

19. Vanderhoff JA, Young RJ, Murray ND, Hanner TL, Kaufman SS. Successful use of a lipid predominant formula in children with short bowel syndrome. J Pediatr Gastroenterol Nutr 1999;29:504. (Abst) 
20. Chu SM, Luo CC, Chou YH, Yen JB. Congenital short bowel syndrome with malrotation. Chang Gung Med J 2004;27:548-50.

21. Sabharwal G, Strouse PJ, Islam S, Zoubi N. Congenital short-gut syndrome. Pediatric Radiol 2004;34:424-7.

22. Konvolinka CW. Congenital short small intestine: A rare occurrence. J Pediatr Surg 1970;5:574.

23. Kern IB, Harris MJ. Congenital short bowel. Aust N Z J Surg 1973;42:283-5.

24. Yutani C, Sakurai M, Miyaji T, Okuno M. Congenital short intestine. A case report and review of the literature. Arch Pathol 1973;96:81-2.

25. Dumke K, Schnoy N. Seltene Beobachtungen eines angeborenen Kurzdarmes. Z Gastroenterol 1974;12:321-5.

26. Royer P, Ricour C, Nihoul-Fekete C, Pellerin D. Le syndrome familial de grfle court avec malrotation intestinale et stnose hypertrophi-que du pylore chez le nourrison. Arch Fr Pediatr 1974;31:223-9.

27. Schnoy N, Bein G, Dumke K. Familiareis Vorkommen des angeborenen Kurzdarmes. Monatsschr Kinderheilkd 1978;126:431-5.

28. Shawis RN, Rangecroft L, Cook RC, Gough DC, Functional intestinal obstruction associated with malrotation and short small-bowel. J Pediatr Surg 1984;19:172-3.
29. Tiu CM, Chou YH, Pan HB, Chang T. Congenital short bowel. Pediatr Radiol 1984;14:343-5.

30. Iwai N, Yanagihara J, Tsuto T, Taniguchi H, Takahashi T. Congenital short small bowel with malrotation in a neonate.

Z Kinderchir 1985;40:371-3.

31. Dorney SF, Byrne WJ, Ament ME. Case of congenital short small intestine: Survival with use of long-term parenteral feeding. Pediatrics 1986;77:386-9.

32. Huysman WA, Tibboel D, Bergmeijer JH, Molenaar JC. Long-term survival of a patient with congenital short bowel and malrotation. J Pediatr Surg 1991;26:103-5.

33. De Backer AI, Parizel PM, De Schepper A, Vaneerdeweg W. A patient with congenital short small bowel associated with malrotation. J Belge Radiol 1997;80:71-2.

34. Schalamon J, Schober PH, Gallippi P, Matthyssens L, Hollwarth ME. Congenital short bowel; a case study and review of the literature. Eur J Pediatr Surg 1999;9:248-50.

35. Ordonez P, Sondheimer JM, Fidanza S, Wilkening G, Hoffenberg EJ. Long-term outcome of a patient with congenital short bowel syndrome. J Pediatr Gastroenterol Nutr 2006;42:576-80. 


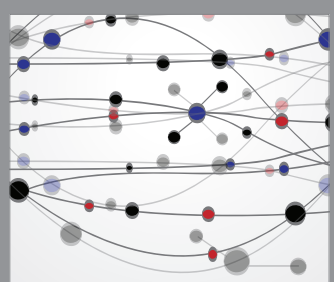

The Scientific World Journal
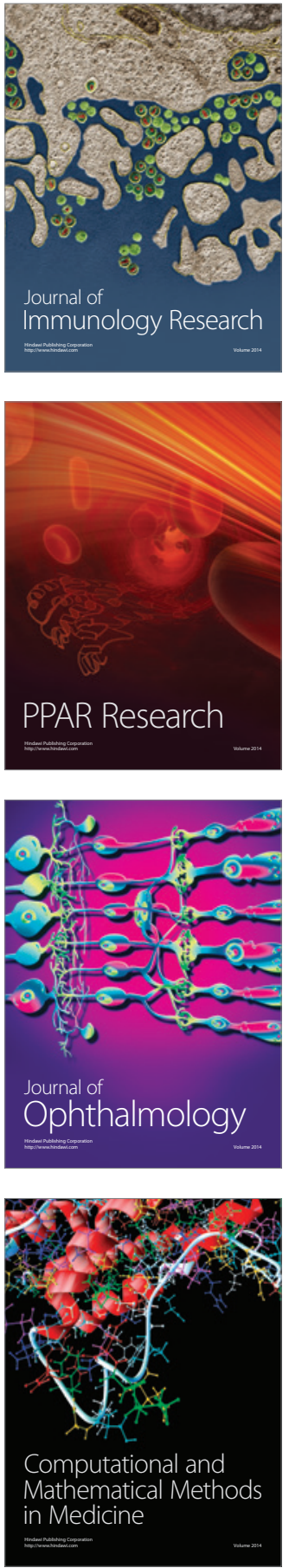

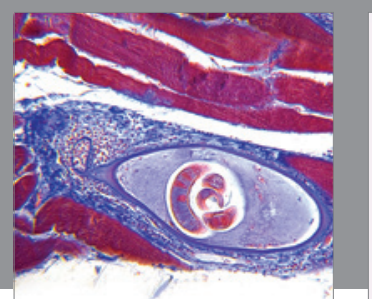

Gastroenterology Research and Practice

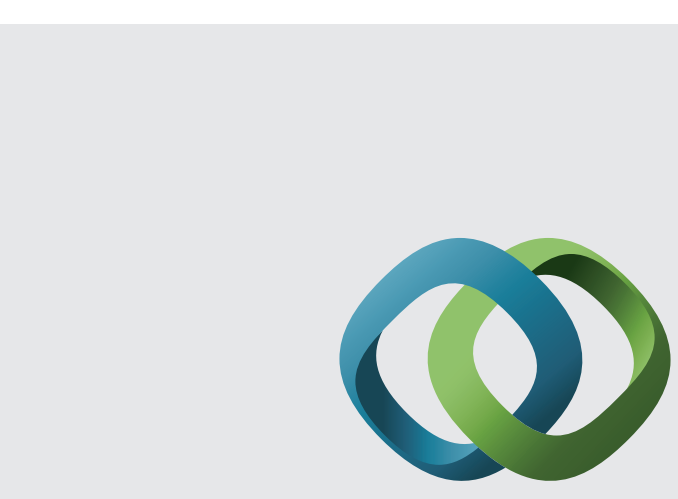

\section{Hindawi}

Submit your manuscripts at

http://www.hindawi.com
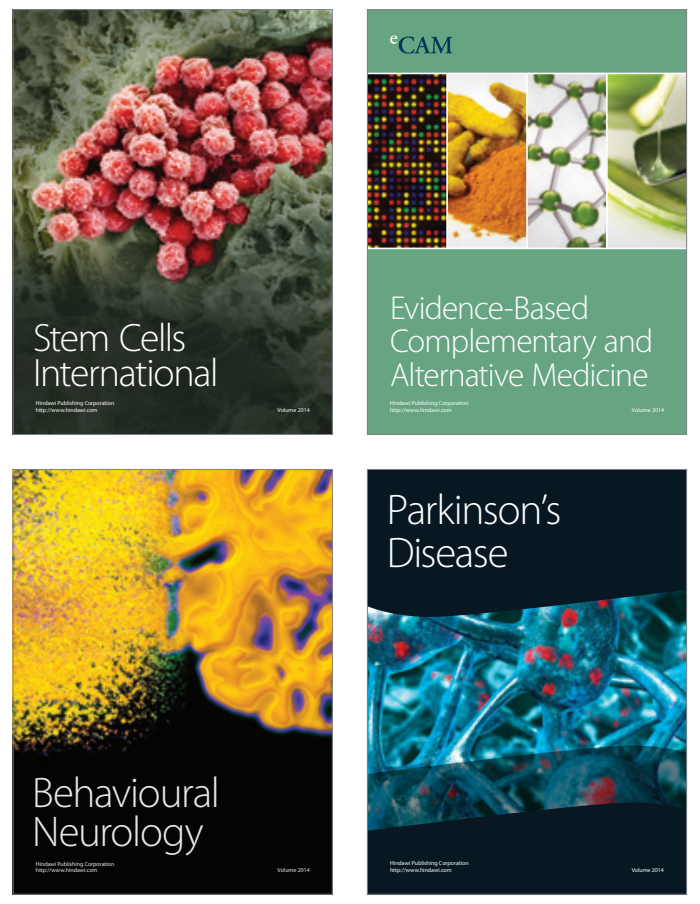
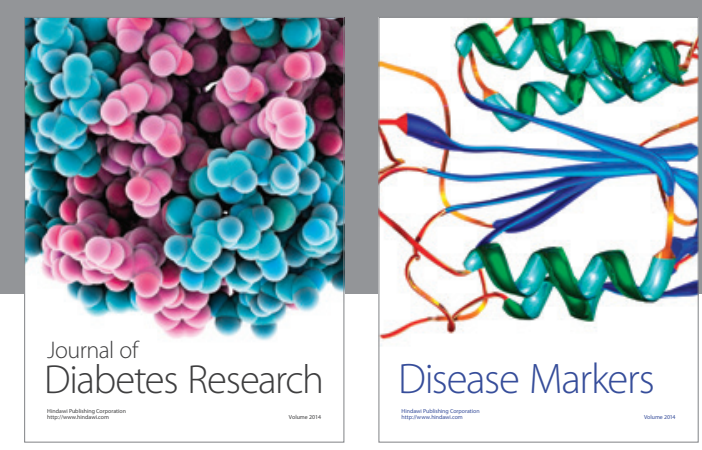

Disease Markers
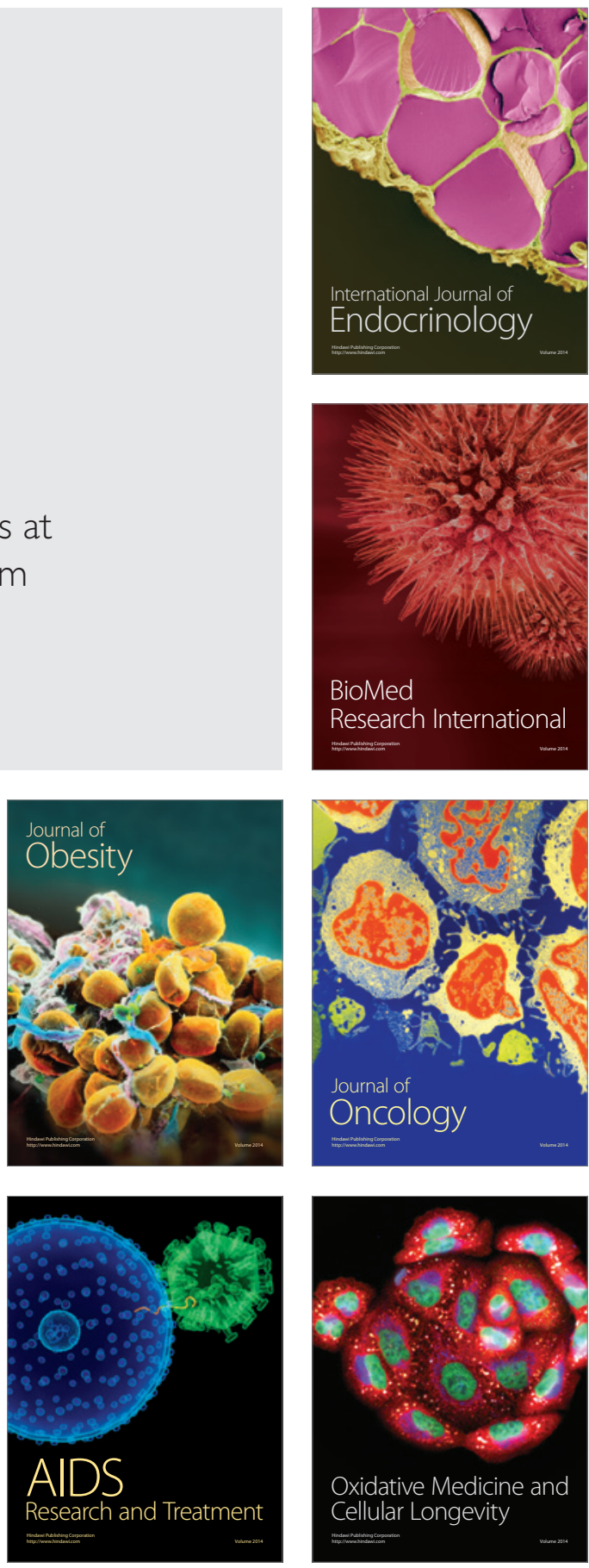